IRSH 56 (20I I), Special Issue, pp. I65-I95 doi:I0.10I7/S00208590I I0005 I 4 (C) 20 I I Internationaal Instituut voor Sociale Geschiedenis

\title{
Work Ethics and Work Valuations in a Period of Commercialization: Ming China, I 500-I $644^{*}$
}

\author{
Christine Moll-Murata \\ Faculty of East Asian Studies, Rubr-Universität Bochum \\ E-mail: Christine.Moll-Murata@rub.de
}

\begin{abstract}
Summary: In global terms, Ming China was one of the largest of the economies and political entities that saw increasing integration. Between I 500 and 1650 it experienced a phase of commercialization that influenced perceptions and valuations of work in various ways. Taking a multi-layered approach, this study explores Confucian tenets that made a distinction between mental and physical work, and between four main occupational groups. It discusses earlier Buddhist perspectives on work which were still valid during the Ming period. Further, the legal regulations concerning work in the Ming penal code and the valuations of work and particular occupations in a contemporary literary source, a carpenter's handbook, and an agricultural guide are probed for direct and indirect evidence of the commodification of work in cities and in the countryside, and of gendered division of labour. A consideration of the usefulness of work songs for studying the self-expression of workers concludes the essay.
\end{abstract}

Among the empires in existence between I 500 and 1650, China stands out for its centralized administration, its large population, and its great historical depth of memory and record, with a particular focus on political philosophy. The period considered in this essay corresponds to the middle and late Ming dynasty (1368-1644), and the rise of the Manchu Qing dynasty (I644-I9I I). During that era, a commercial market system emerged, evidenced by a rise in the number of recorded markets. The influx of silver from the Spanish colonial empire via the Philippines lubricated these expanding market activities. Human labour formed an important element in this nexus of commercialization. Cash-cropping and artisan production became more common for rural households, often involving all family members. Skilled urban professionals were able to concentrate on production for local, regional, and interregional markets.

\footnotetext{
* In this article east Asian names are given in the sequence family name - personal name.
} Exceptions are made in cases where the authors have adopted Western personal names. 
From the perspective of the state, commercialization and the greater liquidity of the economy entailed the corvée duties of the agrarian population being partly transformed into monetary taxation. ${ }^{\mathrm{I}}$ In a similar process, after 1485 professional artisan households which had been registered for periodic service to the state were given the option to pay taxes rather than render labour obligations.

The size of the Ming Empire's population is still being debated. Estimates range from 97 million to I 55 million in I 500 , and from 100 million to anything between I 52, 230, and even 290 million in I644. ${ }^{2}$ One unresolved issue is the impact of climate cooling on living conditions and population size. According to recent estimates, throughout the period I 500-I650 the climate was cooler than at present. The so-called "Little Ice Age" is said to have started in I6I8, when snow fell in subtropical Guangdong province. Droughts, epidemics, and floods occurred frequently in northern China in the I630s and I640s. ${ }^{3}$ In writings that are concerned with work and occupations, reference is seldom made to such hardships, which must have been compounded by the unstable, warlike political situation at the end of the Ming Dynasty. Nevertheless, they should be borne in mind when discussing the human condition at the end of a period of great change and incremental growth.

Exploring the perspectives explained in the Introduction to this volume, this essay focuses on the sources and issues that marked the late Ming period and the transition to the Qing. These layered questions included the identification of texts and traditions referring to work. The question was raised whether the terms for "work" and "worker" reflected appreciation or disdain. The position of work and the worker in society and the valuation of waged labour, also in comparison with other, noncommodified types of labour, was another focal point. Did both free and unfree labour exist? Moreover, we asked according to which criteria particular occupations were ranked. An ethnic or gendered division of labour was a further concern. Finally, were there theories about what constituted "just" remuneration? For a large empire, and a great body of writings that might contain scattered evidence of work-related thinking,

I. Ray Huang, Taxation and Governmental Finance in Sixteenth-Century Ming China (Cambridge, 1974), pp. I I2-I3 I, I I8.

2. The lower estimates are from Cao Shuji, Zhongguo renkou shi. Di si juan: Ming shiqi [Chinese Historical Demography, IV: The Ming Period] (Shanghai, 2000), pp. 34 and 452, and the higher figures are from Martin Heijdra, "The Socio-Economic Development of Rural China during the Ming”, in Denis Twitchett and Frederick W. Mote (eds), The Cambridge History of China, VIII: The Ming Dynasty, Part II (Cambridge, 1998), pp. 417-578, 440. For a critique of the higher figures, see Robert B. Marks, "China's Population Size during the Ming and Qing: A Comment on the Mote Revision"; remarks given at the 2002 Annual Meeting of the Association for Asian Studies, Washington DC, at http://web.whittier.edu/people/webpages/personalwebpages/rmarks/ PDF/Env._panel_remarks.pdf; last accessed I July 20 I I.

3. Heijdra, "Socio-Economic Development of Rural China", pp. 425-427. 
this was a complex task. The aim of this present contribution is to show the variety of approaches to human work in mid- and late-Ming China.

\section{TEXTS AND TERMINOLOGY}

As in many other regions of the world in the sixteenth and seventeenth centuries, descriptive and normative formulations of work and work organizations by urban or rural elites, often those in the service of the state or polity, are the most easily available sources, while written indications of self-perception by working people are rare. Strikes and work riots are reported from the official point of view rather than from the point of view of those actually engaged in labour unrest. "Labour" or "work" is discussed in various contexts.

The texts created by the government which concern work and labour are legislation and administrative regulations. Those were codified in the Great Ming Code, Da Ming lü, of I389, as well as in legal commentaries, in the collected statutes of all administrative branches and ministries of the Ming government ( $\mathrm{Da}$ Ming huiyao), the more detailed statutes and precedents (zeli) of individual ministries, and in handbooks for local officials. A prominent example are the regulations Gongbu changku xu zhi [What Should Be Known about the Working Sites and Storehouses of the Ministry of Public Works $],{ }^{4}$ compiled in I6I5, which constituted the Ministry's supervision and accounting guidelines for its work and maintenance projects.

The sources written by rural and urban elites that refer to work in the private sector also consist of more hands-on compendia concerning agricultural techniques and agricultural home industries, such as agricultural handbooks or encyclopaedias. The purpose of those works is to inform landowners and officials about the most efficient use of material resources and labour and thus, ultimately, to maintain the social order. They are neither "classics of labour", nor exclusively technical compendia

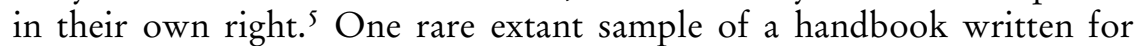
craftspeople, namely carpenters and joiners, is the fifteenth-century "Classic of [the patron saint of construction artisans] Lu Ban".

Family precepts (jiaxun) are another type of source that can be of special use in identifying which professions were the most desirable within particular families or lineages.

4. He Shijin (comp.), Gongbu changku xu zhi [What Should be Known about the Working Sites and Storehouses of the Ministry of Public Works], edition Xuanlan tang congshu xubian, CCXXIII-CCXXV (Taipei, I985).

5. Compare, for instance, Dagmar Schäfer's characterization of the concerns of Song Yingxing, the author of Tiangong kaiwu, as being directed towards the socio-political rather than the scientific or technical field: "The Congruence of Knowledge and Action: The Tiangong kaiwn and its Author Song Yingxing", in Christine Moll-Murata et al. (eds), Chinese Handicraft Regulations of the Qing Dynasty (Munich, 2005), pp. 35-60, 55-56. 
The rise of commercialization during the mid-Ming also found its expression in the genre of merchant route books and manuals, which contain information - interspersed here and there - on ethical maxims in commerce. ${ }^{6}$ In the middle- to late-Ming era, guild houses were founded as hostels and institutions for developing merchant networks based on the principle of a common region of origin. It was only in the eighteenth century that self-characterizations by merchants and also by artisan corporations became more frequent.

"Labour" is expressed by the term lao 勞, which has the connotation of “toil", "pain", and “exhaustion", or qin 勤, which implies diligent or industrious work. Both refer mainly to physical work, especially in agriculture. Another designation for work is gong I. Since this character is derived from a tool-like object, probably a carpenter's square, it is predominantly associated with craft or proto-industrial production. In contrast to lao it can designate the worker as well, and, in addition, in public accounting it is a measure of one day's workload, the average workday. Finally, work in the sense of “making a living”, shenghuo 生活, occurs in many instances in a contemporary agricultural handbook with reference to farmers and farmhands.

In China's political economy since the first millennium $\mathrm{BC}$, the ruler's subjects were obliged to render service to the state in the form of corvée labour. The general term for corvée is $y i$ 役. This was initially associated with military service, but in the Ming dynasty it also referred to service in civilian tasks, mostly in construction and water conservation. Sometimes $y i$ was also combined with lao or gong. In the course of the Ming dynasty, the relatively strict system of artisan registration and work service as a form of tax in kind was gradually replaced by monetary tax payments. For the later developments, especially in the eighteenth and nineteenth centuries, it is interesting to study the change from the concept of $y i$ as "unpaid corvée labour" to "wage labour in the service of the state", which, though it did not exactly imply "free" wage labour, was more emancipated than the restrictive system at the beginning of the Ming dynasty.

A fourth term, $z h i$ 職, which is associated with service for the state, designates both administrative work and the position held by a government official. In comparison with $y i$, this term stands out more constantly during the course of the second millennium.

Further designations of interest for the period in question are "hired labour", guyong 雇傭, or the "hired labourer", gugongren 雇工人, as well as dian 佃, tenancy/bond service, with its extensions diannu 佃僕 “"nearly free”

6. Timothy Brook, Geographical Sources of Ming-Qing History (Ann Arbor, MI, 2002), and idem, "The Merchant Network in I6th Century China: A Discussion and Translation of Zhang Han's 'On Merchants'”, Journal of the Economic and Social History of the Orient, 24 (1981), pp. 165-2I4. 
tenants", nupu 奴僕, “bondservants”, or dianpu 佃奴, “"agricultural bondservants”, and $n u$ 奴, “a person who does service for a particular master and/or manages his land", a term often rendered as "slave".

\section{WORK VALUATIONS: THE POSITIONS AND USEFULNESS OF WORKERS IN SOCIETY}

As a rule, moralist considerations of labour from the Confucian point of view take as their point of departure the statement on the complementary fields of human action: the administrative work of the mind as opposed to subservient physical labour. This can be traced back to the Confucian exegete Mencius (372-28I BC):

Great men have their proper business, and little men have their proper business. Moreover, in the case of any single individual, whatever articles he can require are ready to his hand, being produced by the various handicraftsmen: - if he must first make them for his own use, this way of doing would keep all the people running about upon the roads. Hence, there is the saying, "Some labour with their minds, and some labour with their bodies. Those who labour with their minds govern the others; those who labour with their bodies are governed by the others." ${ }^{\circ}$

The other important model is that of the "four occupational groups" (simin), consisting of scholar/officials, farmers, artisans, and merchants. This can be found in the Guanzi [Master Guan] (third century BC):

They [the people] should not be allowed to dwell together in confusion. If they do so, their speech will become distorted and their work disorganized. For this reason, the sage kings, in situating the gentry, were certain to send them to places of leisure. In situating the farmers, they were certain to send them to the fields. In situating the artisans they were certain to send them to the bureaus responsible for them. In situating the merchants they were certain to send them to the marketplaces. ${ }^{\text {II }}$

Political thought reflecting on these two basic concepts is also interspersed in the works of many Ming thinkers. Recent Chinese historiography emphasizes the fact that a number of Ming philosophers, even if they were

7. Harriet Zurndorfer, Change and Continuity in Chinese Local History: The Development of Hui-chou Prefecture 800 to I 800 (Leiden, I989), p. I99.

8. Joseph P. McDermott, "Bondservants in the T'ai-hu Basin during the Late Ming: A Case of Mistaken Identities", Journal of Asian Studies, 40 (198I), pp. 675-701, 677.

9. Zurndorfer, Change and Continuity in Chinese Local History, p. 199.

ı. The Chinese Classics, II, The Works of Mencius, James Legge (transl.) (Oxford, I895), 2nd rev. edn, “Tang Wan Kung”, pp. 249-250.

I I. Guanzi [Master Guan], Sun Bo (ed. and comm.) (Beijing, 2002), ch. 20, p. I35; "Xiao kuang" [Little Basket], in Allyn W. Rickett's translation, Guanzi: Political, Economic, and Philosophical Essays from Early China (Princeton, NJ, 1985), p. I85. 
not part of the mainstream, no longer believed that the first two of those groups, the scholars and farmers, were the foundation or "roots" of society and that merchants and artisans mere derivatives or "branches" which needed to be kept under control. Such ideas were formulated in collections of essays or works on political practice and statecraft. ${ }^{12}$

For instance, Zhao Nanxing (I550-1627) claimed that all four groups were "fundamental"; ${ }^{13}$ Wang Daokun (I $525-1593$ ) argued that, although in earlier periods taxation had been light for peasants and heavy for artisans and merchants, this should be adjusted, so that the valuation for all groups would be identical in practical and financial terms. ${ }^{\mathrm{I}}$ Feng Yingjing (I555-I606) maintained that merchants were even more important than farmers and shouldered a greater responsibility for securing the subsistence of the people than the other groups. ${ }^{\text {Is }}$ Finally, Huang Zongxi (I6I0-I695) declared that artisans and merchants were already cherished by the ultimate Confucian models of morality, the legendary sage kings of antiquity, and should by all means be considered fundamental. ${ }^{16}$ However, such views remained exceptions to the norm. The dominant view was the conviction that agriculture in combination with subsidiary production, mainly textiles, was of the greatest importance to the state and that specialization in manufacture and commerce was undesired and suspect.

This was the case even though official attitudes towards merchants were often ambiguous. Officials were aware of the important role of merchants, and still seemed very critical of their dealings. One example is given in Zhang Han's (I5II-I593) essay on the four occupational groups. ${ }^{17}$ Timothy Brook has perceptively analysed the section on merchants. Brook's essay shows that despite the traditional view that merchant activities were "secondary" or "derivative", an opinion Zhang Han traced back to the "sage kings" of antiquity, Zhang Han described the merchant networks of his times in detail, and pleaded for taxes on merchants to be reduced on the grounds that this would enhance commerce and thereby

I 2. Zhou Shengchun et al., "Zhongguo lishi shang de nongben gong shang mo sixiang yu zhengfu zhengce de shanbian" [Changes in Chinese Historical Thought on Agriculture as Fundamental and Crafts and Commerce as Secondary Occupations and Corresponding Government Policies], Zhejiang daxue xuebao (Renwen shebui kexue ban) [Journal of Zhejiang University: Humanities and Social Sciences], 34:2 (2004), pp. 13-22, I 8-19.

I3. Ibid., p. I8.

I4. Ibid.

Is. Ibid., p. I9.

I6. Huang Zongxi, Mingyi daifang $l u$ [Waiting for the Dawn, I662], Chongxin shushe (ed.) (1898), "Caiji” [Financial Administration], 3, fo. 42b.

17. Zhang Han, Songzhuang mengyu [Dream Talk from the Pine Window] (Beijing, 1985), ch. 4, "Shiren ji”" [Record of the Scholar-Officials], "Baigong ji” [Record of the Hundred Artisans], "Sannong ji" [Record of the Three Farmers], "Shanggu ji" [Record of the Merchants]. For biographical information on Zhang Han, see Brook, "Merchant Network in I6th Century China”, pp. 173-175. 
actually increase state revenue. ${ }^{18}$ The existence of a profit motive was fully realized and taken for granted. Zhang Han was more critical of artisans and argued strongly that they should return to "fundamental" agriculture, even if that seemed very unlikely. In comparing the profit made from artisanal luxury production and agriculture or home industries, he says that:

This means that a vessel as tiny as a nutshell equals in value a year's farming, or a pattern of thumb's length is equivalent to one year's weaving. It will be extremely difficult to make people do away with luxury and return to frugality. Therefore the intricate carving hurts the farmer, the complex textile patterns harms the weaver. ${ }^{19}$

To the Confucian scholars in the sophisticated urban society of the high and late Ming, the nostalgic notion of merely four occupational groups must have seemed at least ideologically desirable, even though most people were aware of how antiquated it was. In order to drive home the message that scholars and farmers (or scholars, farmers, artisans, and merchants) were the "good", that is fundamental, groups, some writers developed an extensive list of fourteen and even twenty-four groups. For instance, Yao Lü (fl.I 597) explained that in addition to the four respectable and the two tolerable categories (Buddhist monks and soldiers), the following classification applied: "Daoist priests, doctors, soothsayers, astrologers, physiognomists, geomancers, sedan chair carriers, horse dealers, coachmen, shippers, hairdressers, pedicure masters, beauticians, courtesans and prostitutes, actors, acrobats, and bandits". ${ }^{20}$ The author reprimands all those except the first six as being unproductive and vulgar, but also acknowledges that their services were highly cherished by their clients.

There may be an element of irony in this fine categorization of various service trades. Huang Zongxi, the eminent Ming-loyalist historian and political philosopher, more sweepingly blames the "unproductive and parasitic" groups beyond the first four in a typical condemnation of what he thought of as really non-fundamental trades such as those serving for amusement and for religious needs. ${ }^{2 \mathrm{I}}$

\section{BUDDHIST WORK ETHICS: A VARIANT BELIEF SYSTEM}

Time and again, Confucians professed profound contempt for Buddhist and Daoist clergy, whom they considered unproductive. Since education in the Confucian orthodoxy was indispensable for a successful career as an official, and thus for attaining positions esteemed most highly, such dismissive

18. Brook, "Merchant Network in I6th Century China", pp. I87, 208.

19. Zhang Han, "Baigong ji", p. 79.

20. Yao Lü, Lushu [Disclosed Writings], ch. 9, an encyclopaedia from c.r6I I, cited in Xie Guozhen, Mingdai shebui jingji shiliao [Materials for a Socio-economic History of the Ming Dynasty] (Fuzhou, I98I), III, p. 385 .

21. Huang, Mingyi daifang $l u$, fos $4 \mathrm{I} \mathrm{b}-42 \mathrm{a}$. 
reflections on the representatives of the competing belief systems carried particular weight. Needless to say, Buddhist and Daoist clergy saw things quite differently. Moreover, the impact of lay Buddhism became greater during the Song Dynasty (960-I279), and the influence of Buddhism on syncretistic popular beliefs was considerable. In simplified form, Buddhist tenets on work ethics from the eighth to the twelfth centuries can also be found in contemporary family precepts of the mid-Ming.

The monastic population was basically not supposed to work for a living, but instead to achieve spiritual liberation through meditation and religious exercises. The Vinaya (Lü/Ritsu) school of East Asian Buddhism devised elaborate regulations for the behaviour of monks and, on principle, forbade any other way of maintaining one's subsistence than by living on donations or begging. Other schools, especially meditational Buddhism (Chan), emphasized the usefulness of work as a means of regeneration after strenuous meditation practice, but also for the upkeep of the monastic community. The classical adage "one day without work [means] one day without eating" is attributed to one of the founders of Chinese Chan, Baizhang Huaihai (720-8I4). According to his recorded sayings, even as a venerated teacher Baizhang insisted on working physically with the other monks. ${ }^{22}$ This text may represent hagiography, but the general tendency is well attested that Chan monastic communities not only relied on donations but also performed physical labour.

It is traditionally assumed that Baizhang Huaihai established the first rules for the Chan monasteries, ${ }^{23}$ which were adapted and expanded over time. The last great recompilation was made at the command of the Emperor in I 335 and reprinted in $1424 .{ }^{24}$ By then it had become a standard set of guidelines. These rules state, for instance, that if monks are called to work together ( $p$ u qing), they should all comply, with the exception of the elderly and the ill. This rule refers explicitly to Baizhang Huaihai's adage by admonishing the monks that "a day without work is a day without eating". ${ }^{25}$

22. It is said that when the prior of the monastery was unable to bear seeing master Baizhang toiling, he took his tools away from him and asked him to rest. As a result, Baizhang refused to eat; Baizhang Huaibai chanshi yulu [Recorded Sayings of Meditation Master Baizhang Huaihai], alternative title Hongzhou Baizhang shan Dazhi chanshi yulu [Recorded Sayings of Meditation Master Dazhi (Great Wisdom) of the Baizhang Monastery in Hongzhou], p. 7b, in Sijia yulu [Recorded Sayings of the Four Schools], ch. 2, collection Xinzuan xuzangjing [New Edition of Continued Buddhist Scriptures], 69, I 322, electronic database of Chinese Buddhist Electronic Text Association, Chinese Electronic Tripitaka VI.2, released 2009/04/22; last accessed I July 20II, http://www.cbeta.org/result/normal/X69/ı322_00r.htm.

23. Charles Muller, entries "Baizhang qinggui" and "Chixiu Baizhang qinggui", in idem (ed.), Digital Dictionary of Buddhism, http://www.buddhism-dict.net/cgi-bin/xpr-ddb.pl?76.xml+ id\%28\%27b767e-4eo8-6If7-6d77\%27\% 29; last accessed I July 20 I I.

24. Idem, "Chixiu Baizhang qinggui".

25. Chixin Baizhang qinggui [Imperially Commissioned Clear Rules by Baizhang], Dehui (comp.), in Taisho Tripitaka 2025, 48, p. II44a/b, edition The SAT Taizokyo- Text Database 
This could be any type of work which monks might wish to shun, not only work in the fields; Buddhist ceremonies can also be very strenuous and physically demanding.

Buddhist occupational ethics from the Song dynasty are most clearly formulated in two texts from the second half of the twelfth century that were written by lay Buddhists and expressly address all believers, not only the clergy. ${ }^{26}$ They belong to the school of Pure Land or Amidist Buddhism. This school, which was also active during the Ming dynasty, does not strive for gradual or sudden awakening to the truth of Buddhist teachings through meditation during one's lifetime, but hopes that the individual will be reborn into the so-called "Pure Land", or paradise in the West. If that proves impossible, accumulation of karmic merit is the next best option for attaining a position of higher karmic status in the next reincarnation. Work is valued in terms of its usefulness for acquiring better karma, and for helping others to do so. Moreover, work is judged according to the extent to which it allows the worker to maintain the five basic precepts of Buddhism, which are binding for both lay people and the ordained clergy: no killing of sentient beings, stealing, sexual licentiousness, lying, and alcohol. ${ }^{27}$ The "Admonishments for Particular [Types of People]" by Wang Rixiu from I I 60 discusses thirty-six walks of life, varying according to occupation, gender and age group, and personal destiny. ${ }^{28}$ Among these, eighteen groups are distinctly professional.

Seen from the perspective of work ethics, this fascinating sequence contains the message that high and low social positions are predestined by the karmic merit acquired in previous existences, but are by no means unchangeable. The karma of the present and the subsequent existence can and must be shaped and improved by conscious effort. What is specifically bad about butchers, cooks, fishermen, and bird catchers is that they

(1998-2008), http://2 Idzk.l.u-tokyo.ac.jp/SAT/ddb-sat2.php?mode =search\&key=\%E5\% $\% 4 \% \mathrm{~A}_{7}$ $\%$ E8\% Ar $\% 86 \&$ uop $=$ I\&uof $=264 \& \mathrm{ktn}=\& a \mathrm{a}=\& \mathrm{np}=\& \mathrm{~nm}=$; last accessed I July 20 I I.

26. Wang Rixiu (d. I 173), "Tewei quanyu” [Admonishments for Particular [Types of People]], in his Longshu zengguang jingtu wen [Expanded Pure Land Tracts of Longshu], dated I I60; and Yan Bing (d. I 2 I 2), "Xuxiu fangbian men" [Skilful Preaching on [the Topic of] Cultivation]. For bibliographical details, a translation of Yan's text, and a discussion of the differences between both, see Alan G. Wagner, "Practice and Emptiness in the Discourse Record of Ruru Jushi, Yan Bing (d. I 2 I2), a Chan Buddhist Layman of the Southern Song" (unpublished Ph.D. thesis, Harvard University, 2008); available on the author's website at http://rurujushi.com/ Wagner_thesis_Ruru_Jushi_2008-I0-07.pdf; pp. 26, 278, 305ff, last accessed I July 20 I I.

27. W.E. Soothill and Lewis Hodous, A Dictionary of Chinese Buddhist Terms (Hartford, CT, 1937), p. I I 8, wu jie/pañca-veramanī.

28. Wang Rixiu, Longshu zengguang jingtu wen [Expanded Pure Land Tracts of Longshu], Taisho Tripitaka 1970, 47, pp. 269c-275a, edition The SAT Taizokyo Text Database (1998-2008), http://2 Idzk.l.u-tokyo.ac.jp/SAT/ddb-sat2.php?mode=detail\&nonum=\&kaeri= \&mode2 $=2$ \&useid $=1970,47,0258 \mathrm{aO}$ I; last accessed I July $20 \mathrm{II}$. 
kill sentient beings deliberately in order to make a living. The same is true of sericulturalists, and by extension merchants, who might deal in silk. Those responsible for killing were obliged to appeal frequently to Amitabha and to vow that all the sentient beings killed by their direct or indirect action should be reborn in the paradise of the Pure Land. The prostitute and the wine seller are called upon to vow that all those led astray by their doings should likewise be reborn in paradise. Maids and servants should succumb to the destiny that theirs was a subaltern position, but work to improve their positions in this or the next life. The position of the artisan, especially the carpenter, is ambivalent. He is doing good for others by providing them with housing or material objects, but he cannot gain riches through his profession, nor can he afford to live in the houses he has built. Yet working with utmost diligence will also lay the foundations for his karmic improvement. Unexpectedly, the soldier is not condemned for killing living beings. ${ }^{29}$ For this group, service to the state is deemed to be both important and desirable. The text stresses that this class is nourished by the tax payments of the commoners and admonishes soldiers to be aware of that fact. They should be mindful of their task of maintaining peace and of working for the security of the state and the people. ${ }^{30}$

As can be seen from family precepts, such convictions of what was a desirable profession and what was not did not remain confined to the religious realm; they also pervaded the secular sphere to a certain extent. Ideas about enhancing one's karma on more general terms, expressed in so-called "ledgers of merit and demerit" in morality books, but without the direct relationship to professional occupations, originate from the Song, ${ }^{3 \mathrm{I}}$ such as those of Wang and Yan. In the late Ming and early Qing, they were taken up again as ideas about individual self-cultivation took on greater importance and certainty about one's place in society gave way in the course of continued commercialization and growing political and social ambiguity. ${ }^{32}$

\section{LEGAL PROVISIONS ON FREE AND UNFREE LABOUR}

The Great Ming Code was established in several stages soon after the Ming dynasty was founded; it was finalized in 1397 , and applied in

29. Ibid., p. 272 a.

30. Ibid., p. $274 \mathrm{a} / \mathrm{b}$.

31. Cynthia Brokaw, The Ledgers of Merit and Demerit: Social Change and Moral Order in Late Imperial China (Princeton, NJ, 1991).

32. Kenneth Kuan Sheng Chen, Buddhism in China: A Historical Survey (Princeton, NJ, 1964), pp. 436-438, refers to works such as Yüan Liao-fan's (1533-1606) Yinzhi lu [Record of Silent Recompense], or the Buddhist monk Zhuhong's (I535-1615) Zizhi lu [Record of Self-Knowledge]. 
adjudication together with an increasing corpus of sub-statutes. It defined crimes and punishments, and the general principles for the application of the law. ${ }^{33}$ Labour-related legislation concerned administrative tasks executed by officials and sub-officials, military discipline, standards of security, the obligations of hired artisans in government workshops or those that fulfilled corvée duties, particular groups in the household registration system, such as salt producers, and finally convict labour, which was also exploited in salt and iron production. ${ }^{34}$ The disciplinary intention of this codification is very clear, and it extended from minor to capital crimes. Obedience, diligence, and punctuality were instilled in over a million people working in tributary labour relations.

Legislation on labour issues between civilians was not codified into specialized categories. The Ming penal code did specify general classes of crime to which labour conflicts could also lead, such as cursing, physical violence, and homicide. ${ }^{35}$ Philip C.C. Huang has suggested that the Qing code perceived subsistence agriculture on independent family farms as the standard pattern of economic organization..$^{36}$ Accordingly, neither the Qing nor the Ming codes showed much concern with hired wage labour, although its existence is attested to.

To conceptualize the difference between free and unfree labour in Ming China, it is necessary to consider the status of "good" commoners (liang$\mathrm{min}$ ) and that of the debased class (jianmin). These concepts are not clearly defined in the Ming penal code. In Qing law, mean people included "slaves or bondservants (nupu), entertainers, including prostitutes and actors (changyou), and those employees of government offices who were usually referred to as 'yamen runners' (lizu)". ${ }^{37}$ In Ming penal law, the "servants" or "slaves" (nubi, nupu) formed the lowest stratum in society, and an intermediate class of tenant farmers and hired labourers also emerged in that society. The status of the debased class was abolished by government decree between 1723 and $1735 .{ }^{38}$ This explicitly referred to particular regionally confined groups in the empire, such as "musician households" in Shanxi and Shaanxi provinces, "beggar households" or "fallen/lazy people"

33. Jiang Yonglin, "Introduction", in idem (transl.), The Great Ming Code: Da Ming lü, (Seattle, WA [etc.], 2005), p. lv.

34. The Great Ming Code, ch. 2, "Laws on Personnel"; Articles I 82-20I, "Laws on Military Affairs"; ch. 7, "Laws on Public Works"; ch. 3, "Laws on Revenue”, Section I, "Households and Corvée Services".

35. Ibid., ch. 6, Section I, Articles 277-304, "Violence and Robbery"; Section 2, Articles 305-324, "Homicide"; Section 3, Articles 32 5-346, "Affrays and Batteries"; Section 4, Article 347-366, "Cursing". 36. Philip C.C. Huang, Code, Custom, and Legal Practice in China: The Qing and the Republic Compared (Stanford, CA, 200I), p. 2.

37. Anders Hansson, Chinese Outcasts: Discrimination and Emancipation in Late Imperial China (Leiden, 1996), p. I.

38. Ibid., p. 2. 
(duomin) in the Yangzi Delta, and people living on boats (Dan households) in South China, ${ }^{39}$ as well as to hereditary retainers in Huizhou prefecture. ${ }^{40}$

The group of bondservants is the most difficult to define, as has been shown by Joseph McDermott and Harriet Zurndorfer. Their status varied between the extremely unfree and the almost free. The fact that "they could own, inherit, sell, and rent land and moreover, exploit other [bondservants]" complicates the situation. ${ }^{{ }^{\text {I }}}$ As a rule, the bondservants and their families were recorded on the household register of the master; they no longer existed as independent households and often took on the family name of their masters..$^{42}$ Their status could be hereditary or nonhereditary, ${ }^{43}$ and was not in all cases permanent. When people commended themselves to the patronage of powerful households, a phenomenon that increased during the very late Ming years, there were cases where they were not even dispossessed of their property. ${ }^{44}$

The tasks of bonded labourers included services for the landlord, such as security, entertainment, assisting at family rituals, and carrying sedan chairs. ${ }^{45}$ Article 272 of the Great Ming Code specifically forbade the habit of powerful or wealthy households demanding that their tenants carry the master's sedan chairs at no charge as part of their obligations. Instead, the sedan chair carriers had to be reimbursed..$^{46}$ However, from the perspective of the lawgiver this humiliation of the tenants was the lesser offence. Nobody was entitled to be carried in a sedan chair unless with official authorization. Consequently, the breach of the statutory law was a more serious crime, which was sanctioned with corporal punishment of sixty strokes with the heavy stick. ${ }^{47}$ That tenants were randomly used for the purposes of landlords is also remarked on and criticized in a mid-sixteenth century agricultural handbook which lists transport of rice and weighing flour as typical tasks unreasonably demanded of bondservants or tenants. ${ }^{4}$

In the context of labour relations, an important issue is the transition from bonded labour to the freer arrangements of hired labour and tenancy.

\section{Ibid.}

40. Cheng Pei-kai et al. (eds), The Search for Modern China: A Documentary Collection (New York [etc.], I999), pp. 69-70: "Yongzheng's Edict on Changing the Status of the Mean People".

4I. Zurndorfer, Change and Continuity in Chinese Local History, p. 198.

42. McDermott, "Bondservants in the T'ai-hu Basin", p. 679.

43. Ibid., p. 680.

44. Ibid., p. 684 .

45. Zurndorfer, Change and Continuity in Chinese Local History, p. 199.

46. The Great Ming Code, Article 272, p. I I, "Making Commoners Carry Sedan Chairs without Authorization". The paragraph states that sedan chair carriers had to be reimbursed at a rate of 60 cash per day.

47. Ibid.

48. Shenshi nongshu [Mr Shen's Book on Agriculture], alternative title: Bu nong shu, [The Farmer's Help], compiled by Zhang Lüxiang (Beijing, I956), p. 44. 
The transition occurred at a time corresponding roughly to the late Ming and early Qing. From the I 580 s, workers hired for one year or longer were considered legally inferior to their employers. In consequence, crimes committed by hired labourers were sanctioned more harshly than those of their masters or other commoners. For instance, Article 336 of the Great Ming Code, which concerns "Honourable and Mean Persons Striking Each Other", stipulates $\left(\S_{3}\right)$ that striking hired labourers was not punishable if no bone fractures were caused; if fractures occurred, the penalty was to be reduced by one degree from that for ordinary civilians. ${ }^{49}$ The code spells out more crimes that were to be punished with different severity according to the status (slave, hired worker, ordinary civilian) of the person who committed it. It was only in the course of the eighteenth century that the status of the hired labourers was improved..$^{\circ}$

During the Qing dynasty, which had already established its rule in Manchuria by I636, a particular group of bondservants rose to importance. They were specifically subject to the service of the government and military establishment, which was registered in the so-called Eight Banners. Individuals having the hereditary status of bondservant could nevertheless attain official positions of great influence and receive substantial emoluments, as did Cao Yin (1658-17I2), Director of the Imperial Weaveries and Salt Commissioner.

In sum, the Ming Code is explicit about crimes committed while on duty in the service of the state, and crimes involving corporal violence that occurred between private employers and employees. Yet legislative rules for litigation between civilians that concerned wage issues or other labourrelated conflicts not leading to assault and battery were still beyond the focus of mid- and late-Ming legislation. There is sound evidence of such litigation only from the late eighteenth century onward. ${ }^{5 \mathrm{I}}$

\section{THE RANKING OF INDIVIDUAL OCCUPATIONS}

The Ming Code specifies a variety of occupations directly linked to particularly low status. Generally speaking, "mean people" were legally discriminated against and suffered higher penalties than commoners or officials for the same crime. Marriage between those social outcasts and

49. The Great Ming Code, Article 336.

50. Kang Chao, Man and Land in Chinese History: An Economic Analysis (Stanford, CA, 1986), pp. I57, I45; Ėmilija Pavlovna Stuzhina, "The Economic Meaning of Some Terms in Chinese Feudal Handicrafts", Archiv Orientálni, 35 (1967), pp. 232-243.

5 I. See Christine Moll-Murata, "Legal Conflicts Concerning Wage Payments in Eighteenthand Nineteenth-Century China: The Baxian Cases", in Jane Kate Leonard and Ulrich Theobald (eds), Small Currencies Matter: Trade and Transactions in Early Modern East Asian Economies (Leiden, forthcoming). 
commoners was also forbidden..$^{52}$ Musicians and actors were particularly singled out as partners not suitable to marry. ${ }^{53}$

An idea of how particular occupations were ranked can be demonstrated using family precepts, a common genre in the Ming that became even more widespread during the Qing. This was also closely linked to the perception of the four occupational groups and those not covered by these four great categories. The family precepts of the Huo clan in Foshan from I48I, for instance, explain which occupations are to be avoided: gunpowder production, because it is too dangerous and many people die from it - sulphur is bad for one's health; entering kilns and laying bricks (i.e. kiln building) - the kiln might collapse; gelding animals and selling beef those who slaughter pigs should also change their trade; learning martial arts and soldiery; counterfeiting cash and making false silver ingots; catching wild birds or snakes; iron smelting and producing cooking pans, copper gongs, or other metal implements - the danger of fires should not be underestimated; work relating to funerals - only carpentry is acceptable (presumably for coffins); repairing umbrellas, because of the smell; and collecting rags, which is a demeaning job. ${ }^{54}$

From these prescriptions, with their restrictions on occupations that involve the killing of living beings and human death, the fear of high-risk occupations and a certain affinity with Buddhist and Daoist principles can be understood. Such notions certainly prevailed in the greater part of the population. This is not to say that everybody shared the values of the Huos of Foshan, one of the thriving industrial and commercial centres in the vicinity of Canton.

There is a dark side to one of the trades considered respectable in the family precepts of the Huos: carpentry. According to studies by Klaas Ruitenbeek, the reason why it was respected but also feared was that carpenters were thought to be able to influence the fates of those living in the houses they constructed by means of building magic. ${ }^{55}$ The manual for carpenters, $L u$ Ban jing, a rare example of an architectural guidebook written by a practitioner for the practitioner, includes a large variety of protective and harmful charms which can be incorporated into parts of newly built or renovated houses. It also points out which positions are auspicious or ill-fated for any type of construction. The charms described in the book were thought to be able to influence the lives of all humans

52. The Great Ming Code, Articles I 19, I 2 I.

53. Ibid., Article I I9.

54. Ming Qing Foshan beike wenxian jingji ziliao [Economic Materials in Ming and Qing Foshan Epigraphy], Guangdong sheng shehui kexueyuan lishi yanjiusuo Zhongguo gudaishi yanjiushi et al. (eds) (Guangzhou, 1987), p. 476.

55. Klaas Ruitenbeek, Carpentry and Building in Late Imperial China: A Study of the Fifteenth-Century Carpenter's Manual Lu Ban jing (Leiden, I993), pp. 83-84. 
and animals dwelling in the respective houses or stables. A protective charm might be:

If two coins are put on the ridge-pole, one left and one right, long life, wealth and happiness will prevail. The husband will win fame, the son will obtain a noble rank, and titles of honour will be bestowed on the wife. Sons and grandsons will wear robes of office for generations to come. ${ }^{56}$

A negative charm would be: "A broken rice bowl and a single chopstick cause sons and grandsons to end up as beggars. Lacking food and clothing, they will be always cold and hungry, after having sold their house, they will live under bridges or in temples." 57 Both objects were meant to be hidden in the door frame.

The rationality behind the warning to beware of the wrath of carpenters has already been analysed by contemporary observers. Some of them were convinced that this sorcery was justified by the stinginess and maltreatment of carpenters by employers or customers. ${ }^{58}$ Yet, keeping the carpenters contented was not only a matter of fair wages or prices for the labour they performed. As Ruitenbeek explains, the social position of carpenters was very lowly relative to the importance of their technical skills in everyday life. ${ }^{59}$ According to Shi Tianji (I659-after 1737), the author of a household encyclopaedia from Yangzhou, the best way to prevent harmful building magic was to acknowledge the skills of the carpenters and treat them fairly:

In general, sorcery is suggested to carpenters by the clients' exaggerated stinginess and preoccupation with trivialities. In my opinion it is absolutely necessary to serve meat once every four or five days. If in addition to that you put on a friendly face and speak kind words, if you treat them leniently when you know that they are suffering from hunger and cold, then the carpenters will no doubt produce their best efforts for you. ${ }^{60}$

It is thus very likely that carpenters adopted a menacing image which would cause customers to pay the prices and wages demanded in return for a high quality of construction and the security of their homes and families.

One of the most famous characterizations of urban occupations originates from Chen Duo (c.I488-c.I 52 I). Chen held a hereditary office as a guard commander in the large metropolis, Nanjing, but he was also an

56. Ibid., p. 303 .

57. Ibid., p. 30 I.

58. Ibid., p. 89 .

59. Ibid., p. 83 .

60. Ibid., p. I I s, citing the chapter on building in Shi Tianji (i.e. Shi Chengjin), Jiabao quanji [Complete Collection of Household Treasures], published in 1707 and reprinted in 1737. 
accomplished composer, scenario writer, musician, poet, and painter. ${ }^{6 \mathrm{r}}$ In realistic descriptions this author captured what was typical about people from all walks of life in this large city. ${ }^{62}$ Chen did not explicitly rank the occupations, as in family prescriptions or Buddhist exhortations. Rather, his collection of I 36 songs, "Huaji yuyun" [The Entertainer's Abundant Rhymes], covers a wide variety of occupations and professions in manufacture and in the private and public service sectors, as well as in branches of trade, with one song dedicated to each occupation or shop. ${ }^{63}$ The songs were combined in the Chinese conventional order, according to the particular melodies and rhythmic patterns on which they were sung. They are formulated in simple language and enjoyed great popularity. They were first published in a collection of I6I I and reprinted several times.

What strikes the reader about these couplets is the ironic tone of many of them, as well as the hint of social critique, and the sympathy expressed especially with the lowbrows of Nanjing city. In some of the poems, the author takes the perspective of the workers, asserting their importance. The scaffolder says "The scaffold dangles dangerously in the air; if it wasn't for me, who could do this job?", ${ }^{64}$ and the worker who bows cotton to fluff it up, "If you want it warm and cosy, you can't do without me". 65 The connection between the mechanism of supply and demand and the value of goods and services is expressed in many of the verses. The firewood and charcoal dealers are chided for selling their goods at high prices in the cold season, thereby taking advantage of the hungry and poor. ${ }^{66}$ In contrast, the lantern dealers, who sell decorative articles for festivals, should store their goods until next year if customers are "too lazy to buy". ${ }^{67}$

61. William H. Nienhauser, Jr (ed.), The Indiana Companion to Traditional Chinese Literature (Bloomington, IN, I986), p. 235 .

62. Liang Fangzhong, Zhongguo lidai hukou, tiandi, tianfu tongji [Statistics on Chinese Historical Demography, Land, and Land Tax] (Shanghai, I993), p. 203. Data quoted from official sources are given for Yingtian fu, the prefecture which included Nanjing and its rural hinterland. The population in I491 is given as 711,000 , in 1578 as 790,500 .

63. A variant reading of the title is "Guji yuyun". The edition used here is a slightly shortened compilation: Chen Duo, "Huaji yuyun", in Lu Gong (ed.), Mingdai gequ xuan [Selected Songs of the Ming Dynasty] (Beijing, I959), pp. I-2 I, which includes I I 3 songs. Some of the occupations and businesses included in the original text are omitted from the 1959 compilation, such as Confucian scholars, doctors, elementary school teachers, veterinarians, prostitutes, and shops for coffins and funerary clothes. The complete compilation is available online under the title Zuoyin xiansheng jingding Huaji yuyun [Carefully Edited Abundant Rhymes of the Entertainer by Mr Zuoyin] on the website of the China-America Digital Academic Library at http:// ia700507.us.archive.org/I0/items/02 I I08 I 8.cn/02 I I08 I 8.cn.pdf; last accessed I 3 July 20 I I.

64. Chen Duo, "Huaji yuyun”, p. Iо.

65. Ibid.

66. Ibid., p. 17, chaitan hang [Firewood and Charcoal Dealers].

67. Ibid., p. I I, deng shi [The Lantern Market]. 
Chen Duo bestows the most praise on those artisans whose fortunes were based on their skill and industriousness rather than good luck or nobility. For instance, the bricklayer is described as follows:

He handles the plaster until his old age,

He exhausts all his energy over decennia,

And yet, the deer may wander through the [scattered] mansions of the Jins and Zhangs,

Wild grass may grow over the residences of the Wangs and Xies,

Yet there's nothing as durable as the trowel for plastering in his hand. ${ }^{68}$

Honour is likewise accorded to other artisans who are continuously and industriously engaged in production, even though their crafts do not earn them wealth, and even though they sleep little and work until late at night. This includes the wood turners - always sitting with their backs bent - and the felt makers - who have to withstand the stench of their materials. ${ }^{69}$ Greed and acquisitiveness are often commented on ironically. Thus Chen Duo criticizes the midwife who, immediately upon the birth of the child, says that she expects an honorarium for "washing the child on the third day" ${ }^{70}$

Others less fortunate than those who could learn a craft or profession also appear in these verses, and sympathy is expressed for the lot of beggars, peddlers, load carriers, and donkey drivers. ${ }^{71}$ Sarcasm is heaped on service trades that are shown to be superfluous and useless, such as marriage matchmakers, who do not always find perfect matches, ${ }^{72}$ or Daoist and Buddhist clergy, who think more about worldly matters such as food and money than about giving spiritual guidance, or whose reason for turning to Buddha was lost love rather than spiritual awakening, as in the case of the Buddhist nun. Soothsayers, geomantic advisers, who were consulted about the right position for siting graves, and quack doctors also belonged to this category. ${ }^{73}$ Moreover, the author criticizes cheating and fraudulent practices, such as those of building contractors who sold used and rotten materials pretending they were new, and the wasteful

68. Ibid., p. 6, wajiang [The Bricklayer]. The Jins and Zhangs held hereditary high office in the second and first centuries BC. The Wangs and Xies were famous noble families of the third to the sixth centuries AD.

69. Ibid., p. 8, xuanjiang [The Wood Turner], mujiang [The Carpenter], jijiang [The Weaver]; p. 9, zhanjiang [The Felt Maker].

70. Ibid., p. I4, yinpo [The Midwife].

71. Ibid., p. I5, qi'er [The Beggar Boy]; p. I6, tiao dan [Carrying Loads on the Bamboo Pole], gan jiao [Driving the Donkey], tui che [Pushing the Cart].

72. Ibid., p. 9, meiren [The Matchmaker].

73. Ibid., p. 5, daoshi [The Daoist Priest], heshang [The Buddhist Monk], nigu [The Buddhist Nun], miaozhu [The Temple Precept]; p. 6, mingshi [The Fortune Teller]; p. I4, xiang mian [The Physiognomist], wushi [The Shaman], daoren [The Daoist], zangshi [The Funeral Master]; p. Io, mai zhang [The Quack Doctor]. 
lifestyles of those who made excessive profits, such as the salt merchants in charge of the government monopoly on salt, and business brokers in general. ${ }^{74}$ The last group of professions in the collection are those in menial public security service, such as guardsmen at gates, archers, prison wardens, escorts for convicts, and the informants of officials. Quite obviously, the author was well acquainted with these, and considers their services useful, though in some cases gruesome. ${ }^{75}$

In sum, this set of skilled and unskilled occupations in crafts and services and trade establishments of all types conveys a nuanced image of a complex socio-economic structure. Here human labour was highly commodified and commercial transactions were carefully monitored by the municipal authorities. Fairness was valued highly in these verses. It is symbolized in the subsequent poems on shops that sell scales and shops that sell dry measures for grains delivered as tax payment at public granaries. Not all the poems are ironic. Some, such as the latter two, insist on the importance of honesty in producing and selling scales and measures. Behaviour of this type, in addition to skilled work in either trade, as, for example, of the butcher, whose dexterous handling of his knives earned him approval, ${ }^{76}$ is clearly the ideal expressed here. This type of work ethics can be characterized as merchant and artisan ethics.

\section{GENDERED DIVISION OF LABOUR}

As can be seen from the previous source, although not represented to the same extent as male workers, women were all but absent from the streets of Nanjing. Specific poems are dedicated to the Buddhist nun, the prostitute, the female peddler, and the midwife. The fisherman's wife, who mends the nets, is mentioned in the entry on the fisherman's household. ${ }^{77}$

Estimates of the extent of urbanization during the Ming suggest rough figures of between 9 and Io per cent, with great variance among China's macro-regions. ${ }^{78}$ Life in rural settings could imply various degrees of production for self-subsistence and for the market. Between I 500 and 1650 commercialization had also reached the countryside, where the number of

74. Ibid., p. I8, jiahu [The Building Contractor]; p. I7, yanshang [The Salt Merchant]; p. Is, yaren [The Broker].

75. Ibid., p. 20, menzi [The Guardian at the Gate], qianzi [The Policeman], jinzi [The Prison Escort], kuzi [The Bailiff]; p. 21, xun lan [The Street Gate Patrolman], gong bing [The Arrow Shooter], zaoli [The Police Runner], fangfu [The Guardsman in the Prison], laoren [The Old Man who Informs the Officers].

76. Ibid., p. I 8, tubu [The Butcher's Household].

77. Ibid., yubu [The Fisherman's Household].

78. Cao, Zhongguo renkou shi, IV, p. 368. After the capital had been moved from Nanjing to Beijing, the rate of urbanization in the north increased; Cao (p. 219) estimated it at between 17 and I 8 per cent. 
market towns increased. This trend occurred earlier in the north. In the Yangzi Delta it was later, though stronger and more sustained. ${ }^{79}$ For the latter region, Li Bozhong assumes that about 10 per cent of the rural population did not depend on agriculture for a living. ${ }^{80}$

Since the foundation of Imperial China in the third century BC, taxation in kind for farming households included grains and textiles. The theoretical gender division of labour implied that men did the agricultural work and women wove fabrics. This principle was expressed as "nangeng nüzhi" [men plough, women weave]. In her studies on gender and labour in China, Francesca Bray has pointed out that although this norm was maintained as an ideological guideline by all dynasties, in reality it was gradually eroded. ${ }^{8 \mathrm{r}}$

In the Ming dynasty Confucian elites tried to reverse this trend in order to correct conditions towards what seemed to be proper relationships within households. Their efforts, which included reintroducing sericulture and silk weaving in regions where it had long since been abandoned owing to lack of profitability, were also implemented with enthusiasm by the Qing emperors until the eighteenth century. ${ }^{82}$ According to Bray, to Confucian intellectuals and officials "the economic significance of work was at best secondary" ${ }^{83}$ Orthopraxy, doing the right thing at the right time, was at stake when men wove and women worked in the fields or took up other economically profitable occupations such as growing or processing cash crops. ${ }^{84}$ If gender roles in the division of labour were changed, that might endanger social stability and the hierarchical structure of society, with its basic differentiation between those who wielded power in the state and those who were ruled, between the elder and the younger generations, and between the sexes.

Bray demonstrates that the social reality was quite different from what conservatives considered to be the correct order. Some activist local administrators would promote female silk making in districts where it had died out. Among them were the sixteenth-century governor Lü Kun, who tried to reintroduce silk making in the northern province of Shanxi, and the mid-eighteenth century governor Chen Hongmou in neighbouring Shaanxi province. For Lü Kun, women who did not work in sericulture, silk reeling, or silk weaving seemed to be "without occupation", no matter

79. Heijdra, "The Socio-Economic Development", pp. 508-509.

80. Li Bozhong, Agricultural Development in Jiangnan, I620-I850 (Houndmills, I998), p. 23.

81. Francesca Bray, "Towards a Critical History of Non-Western Technology", in Timothy Brook and Gregory Blue (eds), China and Historical Capitalism: Genealogies of Sinological Knowledge (Cambridge, 1999), pp. I 5-209; Francesca Bray, Technology and Gender: Fabrics of Power in Late Imperial China (Berkeley, CA, 1997), pp. 226-237.

82. Bray, "Critical History of Non-Western Technology", p. 197.

83. Ibid., p. I9I.

84. Ibid. 
what other work they actually did. ${ }^{85}$ Meanwhile, especially in the Yangzi Delta, men had long since taken over work in textile production. In the cities they worked as professional high-class silk weavers, and some made a living by calendering, a finishing process in which cotton cloth is pressed by heavy stone rollers. In the course of time, in the rural proto-industry in the Yangzi Delta, entire families would often work either in silk weaving or in cotton production and processing, and no longer produce their own food. ${ }^{86}$

On the other hand, evidence that women did continuously work in the fields, and thus, from the point of view of conservative circles, assumed the role of the men, is not very firm. Li Bozhong observed an actual increase in specialization in agricultural work for men and textile work for women, at least in the Yangzi Delta, with a peak in the mid-eighteenth century. ${ }^{87} \mathrm{Li}$ asserts that there are many indications in mid-Qing sources that women participated in farm work, but this was mostly weeding, harvesting, or pumping water, which, he argues, was not continuous physical labour carried out under great time pressure, unlike preparing the soil or transplanting rice seedlings. ${ }^{88}$ According to this view, women abandoned any previous agricultural occupations for the more profitable textile work of sericulture, silk reeling, and cotton spinning and weaving in those regions where this was possible.

Depending on the respective food crops and textiles, such activities could be even more profitable. From evidence for the nineteenth-century Yangzi Delta, we know that a woman spinning and weaving cotton for 200 working days would earn 83 per cent of what a hired labourer would receive for working I 80 days, and if she were engaged throughout the whole year she could feed herself and I.5 other people. ${ }^{89}$

This suggests that in the economically most advanced regions, gender roles in the division of labour were not inverted, and that the general tendency was for both men and women - and children - to take up or be made to participate in the more profitable occupations, if circumstances permitted. An important source for the situation in the heart of the Yangzi Delta, entitled Bu nong shu [Farmers' Help] or Shenshi nongshu [Mr Shen's Book on Agriculture], was written and circulated in Huzhou prefecture. Its author made suggestions to landowners for the efficient management of estates. In its initial form it can be dated to the last years of the Ming dynasty, in the I640s; additions from later compilers bear the dates I658 and I662.

Next to technical information on the timing of agricultural processes, plant protection, and raising silkworms, the book includes advice on personnel administration, such as wage payments, provisions in kind,

85. Ibid., pp. 186, 197.

86. Ibid., p. 190.

87. Li, Agricultural Development in Jiangnan, p. I47.

88. Ibid., p. 146.

89. Ibid., p. I 50. 
especially food and drink, and the general treatment of farmhands, hired textile workers, and tenants. It also comments on the gendered division of labour and makes observations on smaller family farms. While affirming the tenet that "men plough, women weave", it reported that in this particular region every family was weaving. Advice is given on how to calculate the costs and the gains of hiring two women to weave silk for one year, including their wages and provisions. ${ }^{90}$ About food provisions, the author holds that "although women and girl servants cannot do really hard physical work, they should still get a taste [of good food and drink], because how could someone who never gets a bite of meat for a long time not stretch out their hand and steal it?" ${ }^{\prime 1}$ As for the rations of rice, served in soup and as plain, cooked rice, "women receive half of the male rations". ${ }^{2}$

The section devoted to female employees and female work (nü gong) states that as a rule, in the western villages of Huzhou, they mostly wove cotton cloth, reeled silk, and spun and produced linen, while in the eastern villages they either raised mulberry trees and carried out miscellaneous agricultural tasks or they wove. ${ }^{93}$ Comparing the contribution to household income from female labour and male labour respectively, the author asserts that the fortunes of the family depended on the industriousness of the wife. "Even though she concerns herself only with silkworms and hemp, which does not seem to make much difference for the economic fate of the household, her diligence will cause all other activities to flourish, and her laziness will make them fail." ${ }^{\prime \prime}$ The author does not expressly mention household work and child rearing.

Returning to the question of whether women were engaged in any agricultural labour at all, this handbook, which treats the cultivation of rice, other grains and vegetables, mulberry trees, and cattle raising, does not mention any gendered division of labour for those activities. Women are explicitly mentioned only at one point, where it admonishes the farmer that "wheat should be sown very evenly. Don't save on labour on this or let women or servants be remiss [with this assignment]" ${ }^{95}$

As opposed to India and Japan, ${ }^{96}$ where transplanting rice was one of the prominent tasks of women, there is less evidence in Chinese sources. In a large encyclopaedia, one reference to a rice-transplanting song ("Cha yang ge"), by the author Yang Wanli, has the verses, "The farmers throw the rice seedlings, the farmer women catch them, the small children

90. Shenshi nongshu, p. 20.

91. Ibid., pp. I5-16.

92. Ibid., p. 16.

93. Ibid., p. 45 .

94. Ibid.

95. Ibid., p. 9.

96. For Japan see the contribution by Regine Mathias in this volume. I am indebted to Shireen Moosvi for pointing out that rice transplanting was a female task in Mughal India, and that women rather than men controlled the timing of transplantation. 
pull up the seedlings, the big children insert them." 97 Two more entries are more specific to one particular region. The section on the local customs of the prefecture in the gazetteer for Yunyang in present-day Hubei province ${ }^{9^{8}}$ says that "men and women both transplant rice seedlings, they play the drum and sing with it". ${ }^{99}$ This is even more explicit for Jingzhou prefecture, in the same province. "For transplanting rice seedlings, they often employ women, the men beat the drum to show the rhythm, or they transport the food. When asked, they reply: '[Our] hands and feet are clumsy and slow, not as nimble as those of the girls'."

That the other forty-three references in this encyclopaedia are not gender-specific cannot entirely answer the question, but, as the last one cited shows, the fact that women transplanted rice was so unusual for some observers that they had to inquire about it. Possibly the various risicultural regions of China were characterized by different habits. One sample given in Francesca Bray's work refers to yet another region in Hubei province where women, who might not have belonged to the ethnic Han, worked the earth with a hoe. ${ }^{\text {OI }}$ To the Confucian ideal of decorum, which saw the home as the proper place of female labour, this was a breach in the behavioural code, which might disrupt the social order. ${ }^{\text {IO2 }}$

For promoting the traditional social hierarchy, including the gendered division of labour, Confucian elites and the ruling Manchu emperors provided the public with positive illustrative images of a harmonious agricultural work setting. This can best be seen in the Gengzbi tu [Illustrations of Ploughing and Weaving], an album of illustrations with poems on risiculture and sericulture. It was first published between II 37 and II $45,{ }^{103}$ and was subsequently reprinted and expanded, especially to include poems by Qing dynasty emperors. It was also adapted in Japan and Korea. ${ }^{104}$ Despite its

97. Chen Menglei et al. (compilers), Gu jin tushu jicheng [Collected Charts and Writings Old and New], compiled 1726-1728, photo-mechanical reproduction of the Shanghai edition (1934), ch. 23. 98. In the Ming dynasty, present-day Hubei and Hunan formed Huguang province.

99. Chen, Gu jin tushu jicheng, ch. I 160, vol. I 52, p. 9/2.

Io०. Ibid.

I0I. Bray, "Critical History of Non-Western Technology", p. I97.

102. Note, however, that for northern Jiangsu there is evidence of this type in the work songs that were collected in the twentieth century. "[In the fourth month of the lunar year] Eighteen girls step into the planting rows, but if they're in their planting rows and have no seedlings to transplant, they scold the long-term worker [who did not bring them with enough speed from the seedbed]"; Shi Lin et al. (eds), Zhongguo minjian gequ jicheng. Jiangsu juan [Collection of Chinese Folk Songs. Jiangsu Section] (Beijing, I998), I, pp. I 35-I 36, "Shi'er yue changgong ku" [The Toil of the Long-Contract Worker in Twelve Months].

I03. Keng-tschi t'u, Ackerbau und Seidengewinnung in China; ein kaiserliches Lehr- und Mahnbuch (Hamburg, I913), p. 70.

I04. Ibid., p. 74; Francesca Bray, "Agricultural Illustrations: Blueprint or Icons?”, in idem et al. (eds), Graphics and Text in the Production of Technical Knowledge in China: The Warp and the Weft (Leiden, 2007), pp. 52 I-568, 53 I. 


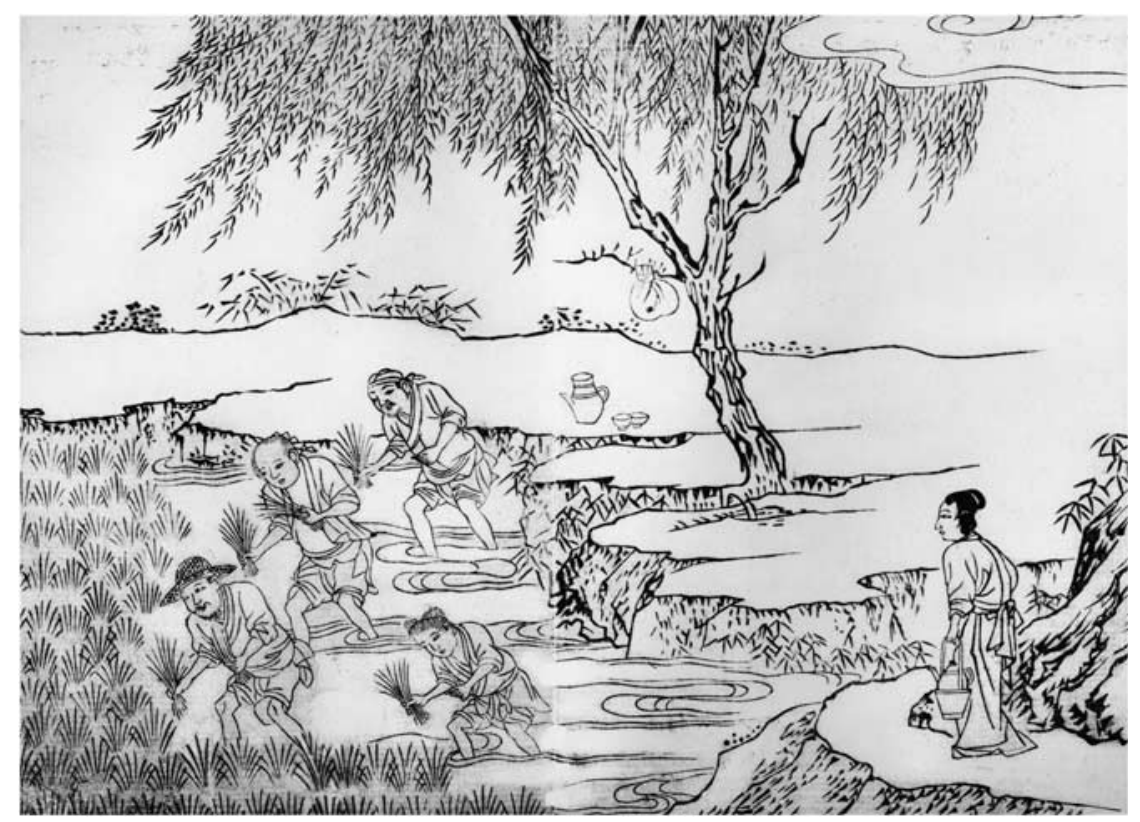

Figure I. The print shows that transplanting rice seedlings was a male task; an onlooker is present, in this case a woman with food containers.

Keng-tschi t'u, Ackerbau und Seidengewinnung in China; ein kaiserliches Lehr- und Mahnbuch (Hamburg, 1913), plate 28, ill. I.9. Japanese reprint, dated 1676, of a Chinese woodblock print edition of $1462 .{ }^{105}$ Reproduced courtesy of Walter de Gruyter publishers, Berlin/Munich. Used with permission.

increasing distance from reality, this was the work that exemplified what, since the twelfth century, had been deemed the proper division of labour: that between men and women, the elder and the younger, the landowning and the employed, and between industrious rice farmers, silkworm raisers, and weavers.

\section{LABOUR CONFLICTS AND WAGES}

Labour conflicts apparently increased in the late Ming dynasty. Some of them were indirectly related to remuneration, but these were no simple wage conflicts such as those that can be found in the legal records of the eighteenth century. Theoretical debates on the concept of a just wage, depending on skill and the specific contracts between employers and

I05. A digital version can be found on the website "Digitale Texte der Bibliothek des Seminars für Wirtschafts- und Sozialgeschichte, Universität Köln”, http://www.digitalis.uni-koeln.de/ digitaletexte.html; last accessed 2 July 20 I I. 
employees, such as the treatise by Zacchia, ${ }^{106}$ were rare in sixteenth- and seventeenth-century China. However, the duration of the working day, as well as details concerning non-monetary remuneration in the form of food and drink played a considerable role in the practical planning and accounting of landlords who employed hired labourers. This is evident from "Mr Shen's Book on Agriculture".

According to the book's author, the exact amount of meat, wine, and rice gruel to be served, and the appropriate timings for the meals, in summer and in winter, greatly influenced worker motivation in a period when the price of labour had increased. ${ }^{107} \mathrm{He}$ gives the following advice:

The old regulations foresaw that as to ploughing, on every man-day one $m u$ [I/6 of a hectare] could be achieved, while as for hoeing, transplanting, and weeding, two $m u$ could be worked per day. In days of old, people were used to hard work, they went out and came back when the stars were shining, their habits were obedient and they would listen to the master's orders. Nowadays, people put on haughty and lazy airs; you can't set them to work without wine and food. This is quite different from one hundred years ago. However, if they only perform their jobs well, and if they are supervised according to the right methods, then it is acceptable if they work less, but diligently, than if they work more, but do it coarsely. As for what is offered to them, it is better to be generous. In the hot season, when the days are long, they will be hungry in the afternoon. On winter days in the severe cold, it is difficult to rise with an empty belly. Therefore, in summer, give them additional foods, and in winter, provide them with hot rice soup in the morning. ${ }^{108}$

The text goes on to explain in detail the usual provisions for workers according to the "old rules", and what was necessary at present. For instance, whereas the previous arrangements envisaged workers in summer and autumn being served meat the first day and vegetables on the two subsequent days, it was now necessary to serve meat every other day. ${ }^{\text {I09 }}$ As for rice wine, the old regulations indiscriminately envisaged one measure for three persons. Now, workers were to be given one measure per person if they performed hard physical labour, a half measure if the tasks were of medium difficulty, and no wine if they performed light work or remained indoors on rainy days. ${ }^{110}$

All of this shows that labour had become scarcer, putting agrarian workers in a better bargaining position; that it was wages in kind, and food and drink in particular, which could make the difference in terms of

106. See Andrea Caracausi's article in the present volume.

107. Shenshi nongshu, p. I3: "Both the prices for (human) manure and for labour have become expensive."

108. Ibid., p. I s.

109. Ibid., p. I6.

I IO. Ibid. 
work motivation; and that an element of efficiency had been integrated compared with the century prior to "Mr Shen's Book on Agriculture". What was at stake here were market conditions, even if this is not directly addressed in the handbook.

Famous cases of labour unrest included those among silk weavers in Suzhou in I60I, who protested against an extra tax imposed on them by a eunuch tax commissioner. They were to pay a fee for every bolt of silk before it was marketed. ${ }^{\text {II }}$ With the tacit support of local elites, a relatively small group of silk weavers protested openly and killed several tax collectors in the town. ${ }^{\text {II } 2}$

A similar situation occurred in the Imperial Porcelain Manufactories in Jingdezhen in the same year, when potters protested, in much greater number than the weavers, against another eunuch director who had tried to extort an impossible number of first-grade porcelain wares from them. A few years earlier, Tong Bin, a kiln worker, had thrown himself into the kiln in despair at the excessive demands being made by the same director. Tong became the patron saint of the Jingdezhen potters. Those potters burned down part of the Imperial Manufactory in 1601 , and production for the state ceased until the end of the Ming dynasty. ${ }^{113}$

A third field of conflict was mining. This was more latent and less focused on one place or one series of events. During the latter half of the Ming dynasty, coal and mineral miners periodically rose up in protest at the manifold state prohibitions on mining operations that were other than very small scale. The government generally suspected miners of unruliness and of having a high criminal potential because they were migrants and difficult to control. ${ }^{\text {II } 4}$

In all three cases or scenarios, the conflicts were reported by the authorities. No texts recording the thoughts or words of the workers themselves have been transmitted down to us. In the first two situations, later historiography sets the issues into the greater context of discontent with the oppressive administration of eunuch officials. The Qing dynasty, which followed the Ming, often used this feature of the late Ming to legitimize its own rule, and was careful especially to lighten taxation and reduce its dependence on eunuchs for administrative purposes.

I I I. Cheng, The Search for Modern China, p. 2.

I I 2. Tsing Yuan, "Urban Riots and Disturbances", in Jonathan D. Spence and John E. Wills (eds), From Ming to Ch'ing: Conquest, Region, and Continuity in Seventeenth-Century China (New Haven, CT [etc.], 1979), pp. 279-320, 287.

I 13. Michael Dillon, "The Porcelain Industry at Ching-te-chen I550-1700", Ming Studies, 6 (1978), pp. 45-53, 50-5 I.

I I 4. Bernd Eberstein, Bergbau und Bergarbeiter zur Ming-Zeit (1368-I644) (Hamburg, I974), pp. I $37-162$. 


\section{THE VOICE OF THE WORKERS: SELF-EXPRESSION IN WORK SONGS}

For the period I 500 to 1650 it is difficult to discern the voice of the workers. Turning to the folk songs collected by nineteenth- and twentiethcentury ethnographers can yield faint echoes of those voices, though. They cannot be dated with certainty, but it is probable that they originated from after 1650. Since the early twentieth century, systematic collection projects have been dedicated to Chinese folk songs and stories. The most recent results of such efforts are two multi-volume series on Chinese folk songs, one edited in Taiwan and the other in the People's Republic of China. ${ }^{\text {II }}$

Important categories within such collections of Chinese folk songs include children's songs, love songs, and work songs (baozi). That work was accompanied by singing in order to keep up the rhythm required for continued repetition of particular procedures can be proven from at least the Han dynasty (206 BC to AD 220). ${ }^{116}$ The term baozi for work songs is more recent and can be dated to the sixteenth century. ${ }^{117}$ Some of the songs in the two collections mentioned refer explicitly to events or objects in the Republic of China or People's Republic of China, and thus reflect the changing situation in the twentieth century. Nevertheless, the collections also contain some features that connect to the sixteenth and seventeenth centuries. One is the typology of work songs, which is related to work procedures already in existence in the late Ming period; another is the protagonists of the songs, who worked in labour relationships which also characterized the period i 500-1650.

Large categories of work songs are the songs for earth pounding and rice transplanting, the songs of the sailors and fishermen, songs for guiding oxen and other animals, for carrying loads, and the songs of the street sellers. These occur, in varying number, in all the provinces in a sample taken here covering Sichuan in the central west, Shanxi in the

i s. Shu Lan (ed.) Zhongguo difang geyao jicheng [Collection of Chinese Regional Folk Songs], 65 vols (Taipei, 1989-), which includes historical sources such as the folk songs found in eighth- and ninth-century Dunhuang documents, and Zhongguo minjian gequ jicheng [Collection of Chinese Folk Songs], 30 vols (Beijing, 1990-2004), which includes over 40,000 songs in a text-critical edition that also offers the music scores. The latter was compiled in a joint project involving several institutions, under the auspices of the Ministry of Culture of the People's Republic of China. Both record folk songs in geographical sequence, by province and smaller administrative units.

I r6. Chen Zi'ai, "Minjian shige gailun” [An Overview of Popular Songs and Poems], Xinjiang Shiyou jiaoyu xueyuan xuebao [Journal of the Xinjiang Petroleum Institute], 4:4 (I997), pp. 90-102, 90.

I 7. Luo Zhufeng et al. (eds), Hanyu da cidian [Great Chinese Dictionary] (Shanghai, I99I), VIII, p. 84I, traces the first reference to Wu Cheng'en's novel Xiyou ji [Journey to the West], first published in c.I 592 . 
north-west, Shandong, Jiangsu, ${ }^{118}$ and Fujian on the east coast, and Guangdong in the south. The categories of labour relations most prominently represented were reciprocal, thus the subsistence farming and household work of the farmers' wives, and commodified labour in the form of long-term or short-term contract workers. One might reasonably surmise that the concentration of explicit social accusation which can be found in the song collections is of a more recent date. ${ }^{\mathrm{II}}$

Social accusation occurred in all provinces; it is inherent in the texts as well as in the titles of the songs, such as those from Sichuan province sung by hired labourers: "The conscience of the boss is black", "The heart of the boss is as vicious as a nail board rake". ${ }^{120} \mathrm{~A}$ similar case is that of the farmer's child bride (tongyang qi or xiao xifu). The system of minor marriage, evident from the tenth century onward, provided for girls to be adopted at a very tender age and raised in the household of their future husband, where they were expected to work for his family. ${ }^{\text {I2I }}$ Songs about the plight of both the hired worker and the child bride, whose husband was often younger than herself, could be heard only faintly, if at all, in the sixteenth and seventeenth centuries, but they became more important as the respective labour regimes disappeared or were formally abolished in the twentieth century.

Two examples from Jiangdu in Jiangsu province north of the Yangzi River, thus not the wealthy part of the Yangzi Delta, contain information worthwhile citing here, even though they probably originated after the seventeenth century. Both are structured in a twelve-month sequence, detailing the hardships for the respective times of the year. The narrative in both cases begins in gloom and ends in downright despair. ${ }^{122}$ The hired worker starts out in the first month seeing wealthy people celebrating the New Year, but he himself wears poor clothing and cannot get his fill with the meagre meals served at his master's house. The young girl is sent, in the first month, to cut reed and wood for fuel in thorny shrubs, which causes injuries and bleeding. She is given heavy chores, the master and his family scold her continuously, the food and clothing are bad. When she becomes ill, nobody troubles to look after her. After demanding that

I 8 . During the Ming dynasty, the province bore the name of its capital, Nanjing.

I 19. This assumption is also supported by an observation in the text-critical remarks in the volume on the Jiangsu folksongs, which point to 1840 (the period of the First Opium War) as a starting point for more articulate expression of worker complaints. See Wu Junda, "Jiangsu min'ge gaishu" [An Overview of Jiangsu Folk Songs], in Shi, Zhongguo minjian gequ jïcheng. Jiangsu juan, I, p. 8.

I 20. Shu, Zhongguo difang geyao jicheng, XLII; idem (ed.), Sichuan min'ge, qingge [Sichuan Folk Songs and Love Songs] (Taipei, 1989), pp. 61, 63.

I 2 I. Hill Gates, China's Motor: A Thousand Years of Petty Capitalism (Ithaca, NY, 1996), p. I 27. I22. Shi, Zhongguo minjian gequ jicheng. Jiangsu juan, I, pp. I34-I35, "Xiao xifu ku'nan ai" [The Child Bride Suffers Hardships], and pp. I35-I 36, "Shi'er yue changgong ku" [The Toil of the Long-Contract Worker in Twelve Months]. 
wood be acquired for her coffin, she sends for her mother, urging "if mother will arrive one step earlier, we will meet, if she arrives one step slower, she will only be able to cry for me". The editors remark that this song was sung during the rice transplanting process, just as the young shoots were being pulled from the seedbed or "mother field" (mutian).

The great variety of tasks carried out by the long-term worker is outlined for each month of the year. During the year, except for bad food and clothing, continuous reprimands for alleged inefficiency oppress him most. Despite the worker weeding, harvesting, and harrowing thirteen $m u$ every day, and scooping river mud for fertilizing five to six $m u$ per day (compare the two $m u$ per day which $\mathrm{Mr}$ Shen thought sufficient), the master still scolds him. However, the worst is at the end: in the twelfth month, after the master has calculated his wages, he learns that he has toiled in vain for a whole year. This topos, which can be attributed to the fact that certain sums for food or debts incurred could be deducted from the worker's wages, also occurs in other songs of long-term workers, for instance in Sichuan. ${ }^{123}$ Yet this is not the entire picture.

Even though labour conditions were oppressive for many of the agricultural population, not all folk songs are work songs, nor do all work songs contain social accusation. In fact, songs of love and courtship prevail in the collections referred to above. Moreover, even though work songs that narrate the position of employers are much rarer, one sample from Shanxi province, again drawing on the twelve-month structure, laments the fact that in the third month workers had to be hired, but that it was very hard to feed them three meals a day, and goes on to enumerate, in the manner of Mr Shen's handbook, all the dishes that needed to be provided. ${ }^{\mathrm{I} 4}$ Finally, there are also songs that express the "Joy of the Farmer":

The joy of the farmer at the end of a prosperous year,

With mild wind and favourable rain,

The sprouts came out well. After weeding several times,

The harvest was good, and he can delight in calmness and leisure. ${ }^{\mathrm{I25}}$

Though one must be cautious about retrospectively attaching meaning from later to earlier situations, the comparison of the clearly datable textual evidence for the mid- and late-Ming period with more recent folk songs highlights issues that can be understood as continuities spanning the centuries: that the incentives to work among all those who were not actual

I23. Shu, Zhongguo difang geyao jicheng, XLII; idem, Sichuan min'ge, qingge, p. 35, "Changgong ge" [The Song of the Long-Contract Worker].

I24. Shu, Zhongguo difang geyao jicheng, LIII, Shanxi, pp. 217-232, "Nongmin shi'er yue" [The Twelve Months of the Farmer], p. 220.

i 25. Ibid., p. 177, "Nongfu le" [Joy of the Farmer]. 


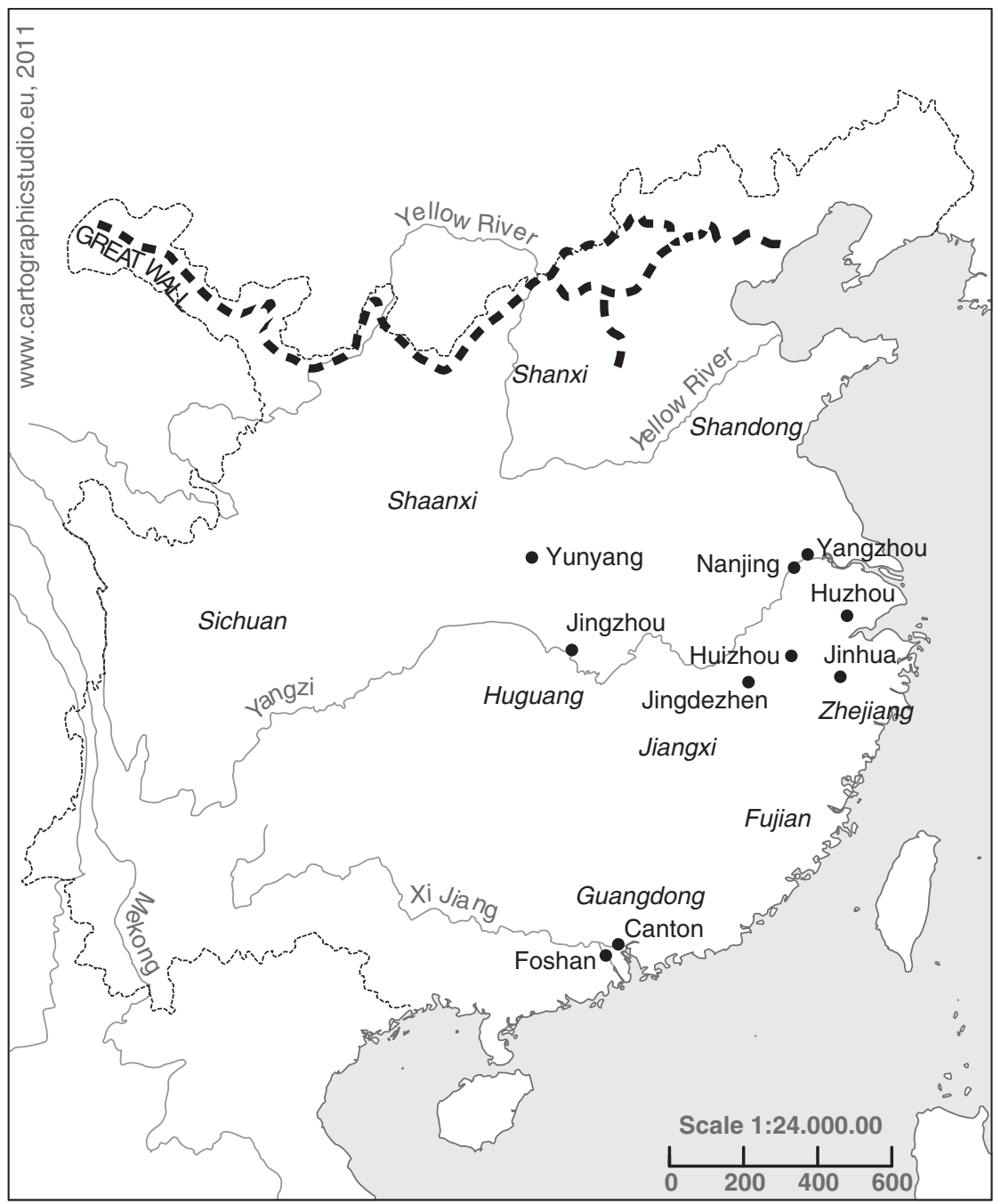

Figure 2. Ming Dynasty China.

family members depended on the investments employers made in terms of monetary remuneration, but much more so on remuneration in kind, and on the social valuation of the workers. Juxtaposing Mr Shen's handbook with the songs of hired workers gives the impression that the bargaining positions of the parties concerned differed markedly over time. However, looking at the small-scale employer of Shanxi province and the Sichuan worker's complaints, the contradiction between employers and employees appears synchronously too. 


\section{CONCLUSION}

The process of commercialization brought about an increase in markets, which entailed a greater volume of marketable products, business opportunities in distribution, and an expansion in workplace production of both basic materials and processed goods. Farms in economic core areas diversified. In the cities, the service sector expanded, meeting every imaginable need of their residents and visitors.

Some representatives of the Ming state lamented these developments. The system whereby a stable, land-based, self-supplying population provided the revenue necessary for the court and state, and whereby a state administration controlled security, justice, and the livelihood of the people through a sophisticated apparatus of public officials deployed throughout the empire seemed to be at stake. For almost 2,000 years, there had been a distinction between physical (subordinate) work and mental (leadership and administration) work. Moreover, occupations were divided into those which served the basic needs of the state, and those in production and distribution which were perceived of as secondary. A third long-held concept was the gendered division of work, with women working in textiles and men working the land.

All of these tenets seemed threatened to some extent as people left the countryside for the cities, merchants and artisans increasingly took on economically prominent roles, men moved into textile work, and entire families, while remaining in their rural settings, left farming and sericulture altogether and turned to more profitable activities. This situation engendered a literature, sometimes beautifully illustrated, on the norms to be preserved, but also on the need to reconsider those norms.

A distinctly variant line of thought linked human activity to precepts that defended the killing of sentient beings, intoxicating the mind, sexual seduction, and religious exercise in order to attain a state from which the chain of reincarnation could be broken. This was not a mainstream conviction in mid- and late-Ming China, but in weaker forms it could be traced back to family rules on which occupations should be avoided. Moreover, there were points where this type of Buddhist belief and the convictions of state Confucianism coincided. Both argued that, because they served the interests of security and state, warriors should not be reproached for killing sentient beings. Moreover, both shared a critique of the profit motive and human acquisitiveness. Yet in other respects related to occupations, they diverged widely, for instance as to the activities of farmers, silkworm raisers, and butchers.

Looking at one particular field of occupation, the building trade, and carpenters in particular, stand out. For reasons also related to commercialization, carpenters had a mixed reputation because they were suspected of magical practices. Beyond the normative formulations from the 
realms of political economy and religion, one famous literary source shows a complete set of all urban occupations in Nanjing city. It gives no explicit ranking, but it also values the occupations in question. This is the perspective of the entertainer. On the one hand it displays sarcasm and exaggeration; on the other it reprimands many of those occupations that the Confucians would also chide, especially the clergy. It professes sympathy with the most destitute, a trait familiar also in Confucian thinking. The importance of professionally maintaining public security is affirmed in the portraits of prison wardens, policemen, and guardsmen of various kinds. Most commendable from this perspective are the skills of the craftsman and the honesty of the merchant in using weights and measures. This specific expression was cherished, in its time and ever since, because of the witty characterization of urban professionalism.

In a much more austere and normative sense, the penal legislation of the Ming conveyed a particular work valuation which basically distinguished between the ordinary commoners, officials, and debased groups for which particular occupations were reserved. Among these, bond service was a changing category which evolved, from the sixteenth to the eighteenth centuries, into arrangements involving tenancy and hired labour.

The intention of this article was to come to a view about the variety of perceptions of labour within the empire of the Ming dynasty, and to show the dynamism and longer continuities in thought about work. Was work becoming a commodified category that could be conceived of as distinctly isolated from "non-work" and "anti-work"? The answer must be in the affirmative. Especially in agriculture, monetary value was expressly attached to the time spent in performing labour. The landlord $\mathrm{Mr}$ Shen formulated the patriarchal attitude that the livelihood of the farmhands should be well provided for, while at the same time the landlord's economic and social status should be maintained. As we see in some of the work songs, workers believed that the treatment by their employers was not benevolent, but exploitative, and that their efforts were not appreciated. In this perspective, work was something to be endured rather than enjoyed, and the only motive for performing it lay in the urge to survive. In the case of skilled craftspeople or independent farmers, and of the large group who worked in the subsistence and household economy, if more autonomous decisions about its organization and production processes were possible, there was also the prospect that work could generate satisfaction and fulfilment. 